\title{
Potential corruption in handling pandemic covid 19: reviewing the provisions article 27 government regulation in lieu of law no. 1 of 2020 and legal problematics
}

\author{
Made Sugi Hartono \\ \{sugi.hartono@undiksha.ac.id\} \\ Universitas Pendidikan Ganesha, Indonesia
}

\begin{abstract}
This study aims to elaborate on the potential for corruption arising from the provisions of Article 27 of the Government Regulation In Lieu of Law Number 1 of 2020. The birth of this provision is a protection for policy makers from being prosecuted civil and criminal as long as it is carried out in good faith and in accordance with statutory regulations. The problem is that this provision opens space for the occurrence of criminal acts of corruption behind the phrase "good faith" which is formulated with multiple interpretations and is subjective in nature. Meanwhile, the Covid 19 pandemic is an emergency condition that threatens the safety of the wider community so that it requires flexibility for the government to take strategic policies. This research is a normative legal research with a secondary database. The data were collected using the document study method on statutory regulations and other literature related to the topic of discussion. The collected data were analyzed and presented descriptively-analytically. Based on the results and discussion, it is clear that corruption has the potential to occur with the provisions of Article 27 of the Government Regulation In Lieu of Law Number 1 of 2020. Government policy in dealing with the Covid 19 pandemic involves a large budget so that each side is prone to abuse of authority. Subsequently, the obscure norm in the phrase "good faith" gave rise to new legal problems. In fact, for a positivistic law, norms must be clearly formulated. The struggle occurs when the interests of the wider community want policies to be taken quickly and effectively in order to save all elements of society. this is the substance of progressive thoughts oriented towards social benefits.
\end{abstract}

Keywords: Corruption; Good Faith; covid-19

\section{Introduction}

The covid 19 pandemic has shocked the world. Neither country has experience in dealing with this virus. Including a large country such as the United States, this country has the highest prevalence rate, namely 7,833, 851 confirmed cases with 215, 199 deaths (WHO Last Updated Data, 16 October 2020)[1].

In the last few months all countries have focused on dealing with covid 19. Including Indonesia, which continues to experience an increase, namely 349,160 confirmed cases with 12,268 deaths (WHO Last Updated Data, 16 October 2020). The government has made every effort to be able to suppress the spread of this virus. Starting from tactical steps by implementing physical distancing, providing logistical assistance to the poor to forming special regulations as a basis for handling the Covid 19 pandemic[1]. 
Government Regulation In Lieu of Law No. 1 of 2020 was born as the legal basis for the government to carry out activities to handle covid-19. This regulation specifically regulates financial policies and financial system stability as a response to the COVID-19 pandemic. More details are regulated in this regulation, namely the government's authority in the field of budgeting in the form of budget devisit restrictions, adjustments, shifts, use of certain budget sources, issuance of letters state debt, determination of sources of budget financing including policies in the field of regional finance, taxation, national economic recovery, financial system stability policies regarding the authority of related institutions such as Bank Indonesia, the Deposit Insurance Corporation, the Financial Services Authority and government policy implementers.

Of the many existing regulations, one of the most interesting is the provision of Article 27 Government Regulation In Lieu of Law No. 1 of 2020 which states that the implementer of the regulation cannot be prosecuted civil or criminal if in carrying out his duties based on good faith and is in accordance with the provisions of laws and regulations. On the one hand, this provision serves as the basis for the legitimacy of government action in dealing with emergency situations in order to act quickly and effectively. On the other hand, the formulation of the phrase "cannot be prosecuted civil or criminal" is very vulnerable to abuse of authority so that it has the potential to lead to criminal acts of corruption. Especially when these provisions depend on the terms of "good faith" which in a legal context are very difficult to prove and are multi-interpretative in nature, so they are called unclear norms[2].

In legal science, the issue of unclear norms is very much avoided. Especially for countries that adhere to civil law systems that make law the main source of law. The provisions stipulated in law must be clearly formulated or known as the lex certa. The basis is the principle of legality. For adherents of legal positivism thought, laws should be enforced as they are. Law enforcement officers are strictly bound in acting according to the formulation of law. They see legal certainty above all else. In fact, in his view justice is born out of certainty. Positivists logically question how they can achieve justice if the enforcement does not maintain legal certainty.

On the other hand, there is a health emergency due to the Covid 19 pandemic which requires fast and effective treatment. Speed of handling is not possible if every action is required to meet the formal procedural. Usually formal procedures take a relatively long time and occur at normal times.

\section{Method}

This paper is a juridical-normative qualitative study that specifically looks at the provisions of Article 27 Government Regulation In Lieu of Law No. 1 of 2020 and its implications for potential criminal acts of corruption. The main issue is about the formulation that is unclear norm, causing multi-interpretation and legal problems derived from it. Secondary data used in this study were collected using the literature study method and document study, especially the legislation and literature related to the study topic. Next, the data set is analyzed using descriptive-analytical techniques so that it is able to provide a comprehensive picture of the topic being studied and its relationship to basic principles and concepts in criminal law.

\section{Result and Discussion}

Lord Acton once warned that Power tends to be corrupt, absolute power is corrupt absolutely[3]. This statement means that the potential for abuse of power is very large for those in power. Moreover, the power possessed is absolute, so acts of corruption are absolute 
as well. According to historical records, Indonesia has experienced a situation where power is so absolute. The New Order government, which was in power for about 32 years, used an authoritarian approach[4]. At the end of his time, President Soeharto was processed based on a criminal court, referring to MPR Decree No. XI / MPR / 1998. However, considering Suharto's health condition, who is permanently ill, the Attorney General issued a Decree on the Termination of Criminal Prosecution[5].

In criminological studies it is known as white collar crime. Sutherland describes the difference between the white collar criminal and crime according to the traditional theory based on poverty, broken homes and disturbed personalities[6]. The perpetrators of white collar crime are committed by people who have high status and respectability[7]. Crime is not committed on the basis of poverty but because of greed. Usually they have enough wealth to live properly.

As a derivative of white collar crime is occupational crime[8]. A person commits a crime by taking advantage of the opportunities that are born from his position legally[9]. This is what is seen as a typology of corruption. Usually crimes are committed by officials of government political institutions[10]. This phenomenon occurs in Indonesia. The following shows the results of research on criminal acts of corruption involving state officials in 2019.

Table 1. Top 10 Number of Corruption Crimes by institution

\begin{tabular}{clc}
\hline No & \multicolumn{1}{c}{ Institution } & Amount \\
\hline 1 & Pemerintah Kabupaten & 95 \\
\hline 2 & Pemerintah Desa & 48 \\
\hline 3 & Pemerintah Kota & 23 \\
\hline 4 & Kementerian & 20 \\
\hline 5 & BUMN & 18 \\
\hline 6 & Pemerintah Provinsi & 16 \\
\hline 7 & Badan/Lembaga Negara & 10 \\
\hline 8 & DPRD & 9 \\
\hline 9 & BUMD Hukum (Kepolisian, & 8 \\
\hline 10 & Penegak Total & 6 \\
\hline & Kejaksaan, dan Pengadilan) & 253 \\
\hline \multicolumn{2}{c}{ Source: antikorupsi.org, Tren Penindakan Kasus Korupsi Tahun 2019. }
\end{tabular}

Based on these data, the third highest number of corruption occurred in district governments with 95 cases, Village Governments with 48 cases and City Governments with 23 cases. These data indicate that corruption is rife at the local government scale. Through the principle of decentralization or regional autonomy, local scale governments have full authority to take care of their own households. This means that local governments are the direct executors of the development program. Of course, there is the use of the budget as capital in program implementation.

Furthermore, there is the principle that the potential for corruption is very high where there is a large swirl of money. This was once stated by Bambang Widjoyanto as a former commissioner of the Indonesian Corruption Eradication Commission. Referring to this, the government has allocated a large amount of funds in handling the Covid 19 pandemic, which is more than Rp. 800 Trillion. The distribution consists of an APBN of Rp. 695.2 trillion, APBD of Rp. 78.2 trillion, and village funds of Rp. 28.46 trillion (CNN Indonesia, 29 
September 2020). This means that in the handling of the Covid-19 pandemic, a large amount of money has been circulated, managed by the government, from planning to program implementation.

This policy is very rational as an ethical and humanitarian demand to save all Indonesian people. The 1945 Constitution through its preamble has emphasized that the state has an obligation to protect the entire Indonesian.

Based on the criminological approach, which is related to the phenomenon of white collar crimes and the principle where corruption works, namely the circulation of large amounts of money, during the handling of the Covid-19 pandemic, it is very vulnerable to corrupt actions. Abuse of authority from policy makers has the potential to occur in at least two things. First, namely the act of embezzling aid money. Second, namely manipulating the data on aid recipients so that there are multiple recipients on the one hand and not receiving assistance at all on the other.

Corruption can destroy the veins, blood flow of a nation. said Mahfud MD's statement which described how destructive the crime of corruption was for the life of a nation. Corruption is seen as an extraordinary crime. Various attempts have been made by the state to eradicate corruption. One of them is by formulating legal provisions in the form of laws that have been updated several times. Finally, namely Law No. 31 of 1999 in conjunction with Law Number 20 of 2001 concerning Eradication of Corruption Crimes. In general, the provisions in this Law regulate severe sanctions in the form of fines, imprisonment to death. Also included is the payment of compensation for the amount of losses incurred by each person's actions.

The provisions of Article 2 paragraph (2) of the Corruption Eradication Law state that the death penalty can be imposed if the criminal act of corruption which is against the law, enriches itself, harms state finances is committed under certain circumstances. Certain conditions are defined as a state of danger in accordance with applicable laws, occurring during natural disasters, a repeat of corruption or a state in a state of economic and monetary crisis.

Indonesia was declared a public health emergency as a result of the Covid 19 Pandemic. Next, through Presidential Decree No. 12 of 2020 the President determined the Covid 19 Pandemic as a non-natural national disaster. Non-natural disasters are defined as disasters that are caused by non-natural events or series of events such as technological failure, failure to modernize, epidemics and disease outbreaks.

\section{Conclusion}

Handling the covid 19 pandemic which uses a budget of up to Rp. 800 trillion are very vulnerable to criminal acts of corruption. Especially with the provision of Article 27 Government Regulation In Lieu of Law No. 1 of 2020 which states that policy makers cannot be prosecuted both civil and criminal as long as it is carried out in good faith and by statutory regulations. This provision serves as a legal umbrella for policy makers who have broad authority in dealing with the Covid 19 pandemic. In an emergency situation, fast and effective action is needed which sometimes carries out legal breakthroughs.

\section{References}

[1] BPKP, “Total Dana Penanganan Corona Rp. 800 T di 2020,” CNN Indonesia, 2020.

[2] S. H. Bhardwaj, "Equality in Law in Context of Abrogation of Article 370 \& 35A of 
Jammu \& Kashmir.," J. Gujarat Reserch Soc., pp. 16-23, 2019.

[3] C. L. Jurkiewicz and R. G. Brown, "Power Does Not Corrupt Absolutely: An Empirical Study," Public Integr., vol. 2, no. 3, pp. 195-210, 2000.

[4] F. Jadidah, "Perubahan Konstitusi Dalam Transisi Orde Baru Menuju Reformasi Di Indonesia," J. Ilm. Mandala Educ., vol. 6, no. 1, 2020.

[5] N. I. Yogadiasti and M. Nazaruddin, "Analisis Framing Berita Meninggalnya Mantan Presiden Soeharto di Majalah Tempo dan Gatra," J. Komun., vol. 3, no. 1, pp. 71-84, 2008.

[6] J. Braithwaite, "White collar crime. Annual Review of Sociology," vol. 11, no. 2, pp. $1-25,1985$.

[7] E. H. Sutherland, "Is' white collar crime' crime?," Is " white collar crime" crime?, vol. 10, no. 2, pp. 132-139, 1945.

[8] K. Holtfreter, "Is occupational fraud 'typical' white-collar crime? A comparison of individual and organizational characteristics," J. Crim. Justice, vol. 33, no. 4, pp. 353$365,2005$.

[9] D. O. Friedrichs, "Occupational crime, occupational deviance, and workplace crime: Sorting out the difference," Crim. Justice, vol. 2, no. 3, pp. 243-256, 2002.

[10] E. R. Quinney, "The Study of White Collar Crime: Toward A Reorientation in Theroy and Research," J. Crim. L. Criminol. Police Sci, vol. 55, p. 208, 1964. 